\title{
Quondam in the Treatises of Tacitus
}

\begin{abstract}
By Tikva Zadok
In studies on Latin adverbs the discussion of a specific temporal adverb in a certain corpus is rare. Moreover, an adverb peculiar to Tacitus' books has not yet been analyzed in the studies concerning his language and style. Our study fills a gap in the researches on adverbs in Latin prose in general and in Tacitus' corpora in particular by examining the characteristic and unique usages of quondam in his treatises. Our grammatical approach adopted here is descriptive. It offers a thorough analysis of a specific adverb in a prose opus of one author, which is a restricted and homogeneous corpus. This enables us to present the full documentation of the adverb under discussion in the selected corpus. Our main results are: quondam functions as a temporal adverb or an adjective in a temporal sense and mostly occurs in Ann. It mainly modifies a finite verb, participial and an apposition. In a few cases it modifies more than one element in a clauselsentence. Its prevalent position is before the modified part of speech. Quondam is sometimes in proximity to a contrasting temporal adverb. A concluding comparison of quondam as an adverb and an adjective between Tacitus' treatises yielded mostly different features.
\end{abstract}

Keywords: Adverb, comparison, finite verb, posteriority, syntactic position

\section{Introduction}

The Purpose, Contribution and Innovation

The purpose of our research is to exemplify by means of a detailed linguistic analysis the characteristic/unique usages, including content/style, of quondam in Tacitus' books. The need for this kind of research arises from a lack of comprehensive analysis of a specific adv. in a certain corpus in general and in Tacitus' treatises in particular. Our innovation and contribution to the studies mentioned below is by an exhaustive discussion of a specific adv. quondam in a specific corpus of Tacitus' treatises.

Selected Studies on Latin Adverbs (in Chronological Order)

\section{$\underline{\text { Studies Dealing with Adverbs in General }}$}

Schafner-Rimann (1958) discusses the adverbial suffix -tim. Menge (1961: $\S \$ 461-498)$ concerns the adv.'s meanings, phrases with similar meaning to the same adv. and adverbial suffixes. Löfstedt (1967) discusses at length the frequency of the advs.' morphemes, noun and adj. as an adv. and the modified part of speech in general. The monumental study of Pinkster (1972) "On Latin Adverbs"

*Post-doctoral Fellow, Tel Aviv University, Israel. 
emphasizes the need for further studies on advs. It contains a description of the advs.' functions in larger constructions, classificatory problems, the syntactic characteristics of advs. and other constituents (adverbial adjuncts, etc). It is not based on quotations from Tacitus' books. Devine and Stephens (2006) "Latin Word Order" deal at length with word order in general without a detailed analysis of a specific adv. in a certain corpus.

\section{$\underline{\text { Studies Dealing with Specific Adverbs }}$}

Booth (1923) deals with the position of measure advs. in Roman comedy and in de Agri Cultura by Cato. Lundström (1961) concerns abhinc and ante with measure adv. in abl./acc. An exhaustive discussion on prae and pro as advs., prepositions and prefixes is offered by Francis (1973: 1-59). Solodow (1978) discusses the functions of quidem and its position. Risselada (1996: 105-125) deals with the functions of nunc as a discourse marker and a temporal complement as compared to now in English.

\section{Selected Studies on the Language of Tacitus and His Style}

Mendell (1911) give a detailed analysis on sentence connection in Tacitus' books. Voss (1963) discusses the emphatic style employed by Tacitus. Kirchner (2001) deals at length with sentences types in Tacitus' works and their functions.

\section{Methodology}

Our methodology and grammatical approach adopted here is descriptive, including quotations from the corpora ${ }^{1}$ with literal translations wherever applicable. ${ }^{2}$ The analysis is described with detailed comparative tables (see Tables 1-6 below). Our discussion contains seven sections: the distribution of quondam in each book and its variants; its meanings as an adv. and an adj. in a temporal sense; its proximity to a contrasting temporal adv. or without it; the part of speech modified by quondam; the position of quondam in relation to its modified element; a comparison of quondam as an adv. and an adj. between Tacitus' books; conclusions.

\footnotetext{
${ }^{1}$ The quotations for our discussion in the corpora are according to the editions of Heubner (1978, 1994), Önnerfors (1983). Slight changes are according to Fisher (1906, 1911), Koestermann (1969, 1970, 1971), Schinzel (1971), Weiskopf (1973), Winterbottom, Ogilvie (1975), Römer (1976).

${ }^{2}$ In the references were indicated the treatise (in Hist. and Ann. also the book number) followed by a number of chapter and paragraph (Ger. 29,1; Hist. 2,9,2, etc.).
} 


\section{The Distribution of quondam in the Corpora and Its Variants}

From Table 1 below, quondam occurs in 50x: Ann.-42x, Hist.-7x, Ger.-1x. ${ }^{3}$ The reading quondam and the phrases, in which it is included, are documented with five variants in $7 x$ :

A. Quamdam: Hist. 2,68,4 (Schinzel 1971: 72).

B. Quosdam: Hist. 2,9,2 (Schinzel 1971: 72); Ann. 11,20,1 (Fisher 1906: 222,

Koestermann 1971: 213, Weiskopf 1973: 24, Heubner 1994: 224).

C. Quodam: Hist. 3,47,1 (Fisher 1911: 141; Koestermann 1969: 136).

D. Condam: Ann. 16,10,4; 17,2 (Römer 1976: 131, 141).

E. Quondam without ut: Ann. 16,22,2 (Römer 1976: 148).

Table 1. The Distribution of Quondam in the Corpora

\begin{tabular}{|l|l|c|}
\hline Book & \multicolumn{1}{|c|}{ References } & Cases \\
\hline Ann. & $1,8,5 ; 9,1 ; 12,4 ; 54,1 ; 63,4 ; 77,3 ; 2,27,2 ; 60,3 ; 63,1 ; 71,2 ; 80,2 ; 3,6,2 ;$ & \\
& 16,$4 ; 23,1 ; 33,4 ; 34,4 ; 56,4 ; 60,3 ; 69,5 ; 4,14,3 ; 25,1 ; 27,1 ; 31,3 ; 73,4 ;$ & 42 \\
& $6,7,2 ; 27,1 ; 37,3 ; 40,2 ; 47,1 ; 50,1 ; 11,1,1 ; 20,1 ; 12,22,2 ; 39,2 ; 56,1 ;$ & \\
& $13,55,2 ; 14,18,2 ; 15,26,3-27,1 ; 71,4 ; 16,10,4 ; 17,2 ; 22,2$ & \\
\hline Hist. & $1,46,1 ; 2,9,2 ; 68,4 ; 3,43,1 ; 47,1 ; 5,4,2 ; 7,2$ & 7 \\
\hline Ger. & 29,1 & 1 \\
\hline Ag. & - & - \\
\hline Dial. & - & - \\
\hline \multicolumn{2}{|l}{ General Total } & 50 \\
\hline
\end{tabular}

\section{The Meanings of Quondam in the Corpora}

As emerged from table 2 below, quondam is used for two descriptions in the corpora: a temporal adv. (33x) "formerly, in the past, once", and an adj./quasi-adj. in a temporal sense (17x) "former, previous" (see OLD: 1567c, s.v. quondam, $\mathrm{adv} ., 1 \mathrm{a}-\mathrm{b})$ like ante, antiquitus. The alternative usages of the synonymous advs. are, inter alia, for variety and a stylistic characteristics of the author (for synonymous words in Latin see, e.g., Menge 1961, 1988).

In other corpora quondam also means "sometimes, at times" (like aliquandō, modo, nunc) or it refers to the future "at some future time, some day". 5

\section{Temporal Adverb}

Referebat habitasse quondam septingenta milia aetate militari

"(One of the senior priests) reported that seven hundred thousand (men) of military age had once dwelt (in Thebes)" (Ann. 2,60,3).

${ }^{3}$ Cf. Gerber, Greef 1877-1890, 2: 1347-48, s.v. quondam; Blackman, Betts 1986, 2: 1516-17.

${ }^{4}$ For this meaning see L, Sh: 1519a, s.v. quondam, adv., I; OLD: 1567c, s.v. quondam, adv., 1a-c.

${ }^{5}$ See L, Sh: 1519a, s.v. quondam, adv., II. A. B.; OLD: 1567c, s.v. quondam, adv., 2-3. 
Adjective or a Quasi-Adjective

Subita per Pontum arma barbarum mancipium, regiae quondam classis praefectus, moverat

"A barbarian slave, the former prefect of the royal fleet, had excited a sudden uprising in Pontus" (Hist. 3,47,1).

Table 2. The Meanings of Quondam in the Corpora

\begin{tabular}{|l|c|c|}
\hline Meaning & References & Cases \\
\hline \multirow{3}{*}{ Adv. } & Ger. 29,$1 ;$ Hist. $3,43,1 ; 5,4,2 ; 7,2 ;$ Ann. $1,8,5 ; 9,1 ; 12,4 ; 54,1 ; 63,4 ;$ & \\
& $\begin{array}{c}77,3 ; 2,27,2 ; 60,3 ; 71,2 ; 80,2 ; 3,6,2 ; 16,4 ; 23,1 ; 33,4 ; 34,4 ; 56,4 ; 60,3 ; \\
4,25,1 ; 6,40,2 ; 50,1 ; 11,1,1 ; 12,22,2 ; 39,2 ; 56,1 ; 13,55,2 ; 14,18,2 ;\end{array}$ & 33 \\
& $15,26,3-27,1 ; 71,4 ; 16,22,2$ & \\
\hline Adj. & $\begin{array}{c}\text { Hist. } 1,46,1 ; 2,9,2 ; 68,4 ; 3,47,1 ; \text { Ann. } 2,63,1 ; 3,69,5 ; 4,14,3 ; 27,1 ; \\
\text { 31,3;73,4;6,7,2;27,1;37,3;47,1;11,20,1;16,10,4;17,2 }\end{array}$ & 17 \\
\hline \multicolumn{2}{|l}{ General Total } & 50 \\
\hline
\end{tabular}

\section{Quondam in Proximity to a Contrasting Temporal Adverb or without It}

From table 3 below, quondam is in proximity to one of eight temporal advs. for emphasis, contrast, etc. in $12 \mathrm{x}$ (8x-quondam adv., $4 \mathrm{x}$-adj.). It is not next to a contrasting temporal adv. in 38x (25x-quondam adv., 13x-adj.).

Quondam in Proximity to a Contrasting Temporal Adverb

Quondam: Adverb

Posterior adverb

$\underline{\text { Tum/tunc }}$

Ne Tigranes quidem, Armenia quondam potitus ac tunc reus, nomine regio supplicia civium effugit

"Even Tigranes, who had formerly ruled Armenia and thereafter was a defendant, did not escape from the punishments of the (Roman) citizens on account of his royal title" (Ann. 6,40,2).

Mox: tum ... mox ... quondam

$\underline{\text { Tum lustratum rite exercitum ad contionem vocat ... mox iter L. Lucullo quondam }{ }^{6}}$ penetratum, apertis ${ }^{7}$ quae vetustas obsaepserat, pergit

"Then after the customary purification (of the army Corbulo) called the army to a meeting ... then he proceeded along the route once penetrated by L. Lucullus, opening up (these places), which time had obstructed" (Ann. 15,26,3-27,1).

\footnotetext{
${ }^{6}$ Quondam refers to L. Lucullus' campaign to Tigranocerta in 69 B.C.

${ }^{7}$ According to Miller (1994: 77), eis "these places" (the antecedent of the following rel. cl.) is supplied and replaces a subject of the abl. absol. (its predicate is apertis). Cf. Ash 2018: 144.
} 
$\underline{\text { Post: quondam ... mox ... post }}$

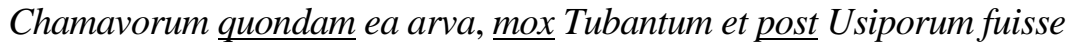

"(Boiocalus reported) that these fields had once belonged to the Chamavi, thereafter to the Tubantes and later to the Usipi" (Ann. 13,55,2).

Mox and post are posterior to quondam, while post took place after mox.

Postea: see Ann. 3,34,4 below.

Present Adverb

Nunc

'Ut quondam C. Caesarem' inquit 'et M. Catonem, ita nunc te, Nero, <et〉 Thraseam avida discordiarum civitas loquitur'

“"As once' (Capito) said 'our country in its eagerness for discord (talked of) C. Caesar and M. Cato, so now it talks of you, Nero, and of Thrasea' " (Ann. 16,22,2).

Iam: see Ann. 3,6,2 below.

Quondam ... nunc ... iam

Pervicacibus magis ... mulierum iussis, quae Oppiis quondam aliisque legibus constrictae, nunc vinclis exsolutis domos fora, iam et exercitus regerent

"The women's orders are the more headstrong ... who were formerly restrained by the Oppian and other laws, (but) now having thrown off (their) bonds they were ruling (our) homes, courts (and) now even our armies" (Ann. 3,33,4).

Iam replaces nunc (instead of the anaphora nunc ... nunc) and is strengthened by et "even".

\section{Quondam: Adjective}

Posterior adverb

$\underline{\text { Mox }}$

Primus Ornospades multis equitum milibus in castra venit, exul quondam et Tiberio, cum Delmaticum bellum conficeret, haud inglorius auxiliator ... $\underline{\text { mox }}$ repetita amicitia regis ... praefectus campis

"Ornospades, a former exile and not an inglorious adjuvant of Tiberius, arrived first in the camp with many thousand cavalry when he was stamping out the Dalmatian war ... later he had regained his king (Artabanus') friendship ... (and) was appointed (governor) of the plains" (Ann. 6,37,3).

There is a contrast concerning time quondam $\neq$ mox and content exul et Tiberio haud inglorius auxiliator $\neq$ praefectus campis: formerly Ornospades had 
been an exile and an adjuvant of Tiberius. Later he was appointed governor of the plains.

\section{Nuper}

Nam hic quondam praefectus praetorii et consularibus insignibus donatus ac nuper crimine coniurationis in Sardiniam exactus

"For Rufrius Crispinus, formerly a commander of the praetorian guard and had been rewarded with consular insignia, but recently was exiled to Sardinia on a charge of conspiracy" (Ann. 16,17,2).

$\underline{\text { Posthac }}$

Ann. 6,7,2 below: there are consecutive events: Servaeus and Minucius were brought to trial (posthac inducti) after Servaeus was formerly a companion of Germanicus (quondam Germanici comes).

$\underline{\text { Tum }}$

Praetorii praefectos sibi ipsi legere, Plotium Firmum e manipularibus quondam, tum vigilibus praepositum

"The (soldiers) chose their own praetorian prefects, Plotius Firmus formerly of the ranks (and) afterwards a commander of the watch" (Hist. 1,46,1).

\section{Lack of a Contrasting Temporal Adverb}

Quondam: Adverb

Impulit, dum ... amitam Scriboniam, quae quondam Augusti coniunx fuerat ... ostentat "(Firmius Catus) impelled (Drusus), while pointing to ... (his) paternal-aunt Scribonia, who had formerly been Augustus' spouse" (Ann. 2,27,2).

\section{Quondam: Adjective}

Oscum quondam ludicrum, levissimae apud vulgum oblectationis, eo flagitiorum et virium venisse, <ut> auctoritate patrum coercendum sit

"(Tiberius said that) the old Oscan farce, the lightest amusement among the crowd, had become such indecency and violence, that it must be checked by the authority of the senate" (Ann. 4,14,3). 
Table 3. Quondam in Proximity to a Contrasting Temporal Adverb or without It

\begin{tabular}{|c|c|c|c|}
\hline $\begin{array}{l}\text { A Temporal } \\
\text { Adverb }\end{array}$ & References & Cases & Total \\
\hline $\begin{array}{l}\text { Quondam: adv. } \\
\text { Posterior adv.: } \\
\text { tum/tunc } \\
\text { Mox: tum ... mox ... } \\
\text { quondam } \\
\text { Post: quondam ... } \\
\text { mox ... post } \\
\text { Postea }\end{array}$ & $\begin{array}{l}\text { Ann. 6,40,2 } \\
\text { Ann. 15,26,3-27,1 } \\
\text { Ann. } 13,55,2 \\
\text { Ann. 3,34,4 }\end{array}$ & $\begin{array}{l}1 \\
1 \\
1 \\
1\end{array}$ & 4 \\
\hline $\begin{array}{l}\text { Present adv.: } \\
\text { nunc } \\
\text { Iam } \\
\text { Quondam ... nunc } \\
\text {... iam } \\
\end{array}$ & $\begin{array}{l}\text { Ann. 3,56,4; } 16,22,2 \\
\text { Ann. 3,6,2 } \\
\text { Ann. 3,33,4 }\end{array}$ & $\begin{array}{l}2 \\
1 \\
1\end{array}$ & 4 \\
\hline $\begin{array}{l}\text { Quondam: adj. } \\
\text { Posterior adv.: } \\
\text { mox } \\
\text { Nuper } \\
\text { Posthac } \\
\text { Tum }\end{array}$ & $\begin{array}{l}\text { Ann. } 6,37,3 \\
\text { Ann. } 16,17,2 \\
\text { Ann. 6,7,2 } \\
\text { Hist. } 1,46,1\end{array}$ & $\begin{array}{l}1 \\
1 \\
1 \\
1\end{array}$ & 4 \\
\hline $\begin{array}{l}\text { Lack of a } \\
\text { Temporal Adverb } \\
\text { Quondam: adv. }\end{array}$ & $\begin{array}{l}\text { Ger. } 29,1 ; \text { Hist. } 3,43,1 ; 5,4,2 ; 7,2 ; \text { Ann. } 1,8,5 ; 9,1 ; \\
12,4 ; 54,1 ; 63,4 ; 77,3 ; 2,27,2 ; 60,3 ; 71,2 ; 80,2 ; \\
3,16,4 ; 23,1 ; 60,3 ; 4,25,1 ; 6,50,1 ; 11,1,1 ; 12,22,2 ; \\
39,2 ; 56,1 ; 14,18,2 ; 15,71,4\end{array}$ & 25 & \\
\hline Quondam: adj. & $\begin{array}{l}\text { Hist. } 2,9,2 ; 68,4 ; 3,47,1 ; \text { Ann. 2,63,1; 3,69,5; 4,14,3; } \\
27,1 ; 31,3 ; 73,4 ; 6,27,1 ; 47,1 ; 11,20,1 ; 16,10,4\end{array}$ & 13 & 38 \\
\hline
\end{tabular}

\section{The Part of Speech modified by quondam in a Clause/Sentence}

The part of speech modified by quondam is explicit (except for 2x). It is mentioned in the cl., in which quondam is included, and rarely in the cl. precedes/ follows quondam. In a few cases the adv. modifies more than one element. The grammatical forms modified by it are as follows:

Quondam: adv. A. Finite verb-13x: 1) P.q.p.-10x (1x + dat. in idiom). 2) Perf.-2x. 3) Fut. II-1x; B. Participia-11x: 1) P.P.P.-10x: a) Replaces a cl.-9x (1x + adj. [attribute]). b) Perf. pass. without esse-1x. 2) P.P.A. [attribute] + adj. [attribute]-1x; C. Inf. perf. act./pass.: predicate of AcI-5x; D. Adj.-4x: 1) Attribute-3x. 2) Predicate of abl. absol.$1 \mathrm{x}$. 
Quondam: adj. A. Noun ${ }^{8}-2 x$; A.a) Apposition-10x; A.b) Subst. adj. in apposition-1x; B. Adj. [attribute]-3x; B.a) Noun + adj. [attribute]-1x. For references see table 4 below.

In the quotations of this section, the relevant element modified by quondam, is underlined.

Quondam: Adverb

\section{The Part of Speech Is Explicit}

Finite verb

\section{Pluperfect}

(1) Iram eius lenivit, pridem invisus, tamquam ducta in matrimonium Vipsania ... quae quondam Tiberii uxor fuerat "(Asinius Gallus) did not soften (Tiberius') anger, for (Gallus) had long been detested (by Tiberius) because of his marriage to Vipsania ... who had formerly been Tiberius' wife" (Ann. 1,12,4).

On the quasi-causal meaning of tamquam see, e.g., Goodyear 1972: 180.

(2) Idem annus novas caerimonias accepit addito sodalium Augustalium sacerdotio, ut quondam $T$. Tatius retinendis Sabinorum sacris sodales Titios instituerat "The same year acquired new ceremonies when an office of Augustal priests was set up, just as in former days T. Tatius had founded the Titian Fellows to preserve the rites of the Sabines" (Ann. 1,54,1).

(3) Populumque edicto monuit ne, ut quondam nimiis studiis funus divi Iulii turbassent, ita Augustum "(Tiberius) warned the people by an edict that (they will not disturb the funeral) of Augustus, as they had formerly disrupted by their excessive enthusiasm the funeral of the deified Julius" (Ann. 1,8,5). ${ }^{9}$

In Idiom: Dative + P.Q.P.

Neroni invisus, quod Poppaeam quondam matrimonio tenuerat

"(Rufrius Crispinus) was hated by Nero, because he had formerly been married to Poppaea" (Ann. 15,71,4).

In the Clause Following quondam: Ann. 12,56,1 below.

\footnotetext{
${ }^{8}$ For an adv., which rarely modifies a noun in Latin, see Kühner and Stegmann 1962, 2/1: §59; Leumann, Hofmann, Szantyr 1963, 1: §101, b.

${ }^{9}$ See also Ann. 2,27,2 above; Hist. 3,43,1; 5,4,2; Ann. 1,77,3; 12,39,2 (quondam modifies excisi + traiecti forent) below.
} 
Perfect

Eamque aetatem, qua ipse quondam a divo Augusto ad capessendum hoc munus vocatus sit. Neque nunc propere

"(Tiberius pointed out that Drusus was) of the same age (as himself), when (Tiberius) himself had formerly been sommoned by the divine Augustus to undertake this office. Nor (was it) now hastily (he added)" (Ann. 3,56,4).

In The Clause Following quondam

Ann. 16,22,2 above: loquitur is modified in the main cl. ita ... loquitur by nunc in present without repetition of it in the comparison cl. ut ... Catonem with quondam.

Future Perfect: Ann. 3,6,2 below.

Participia

P.P.A. (Attribute) + Adjective (Attribute)

Si quos spes meae ... erga viventem movebat, inlacrimabunt quondam florentem et tot bellorum superstitem muliebri fraude cecidisse

"If my hopes ... moved anyone towards the living (man), they will shed tears that (a man) once flourishing and survivor of so many wars has fallen by a woman's deceit" (Ann. 2,71,2).

P.P.P.

Replaces a Clause

(1) Plerisque vana mirantibus quod idem dies accepti quondam imperii princeps et vitae supremus. "Many people expressed wonder over the idle (topics) that the same day, on which (Augustus) formerly assumed sovereignty, (was) the first and also the last of his life" (Ann. 1,9,1).

(2) Non pugnaturis militibus, ubi Pisonem ab ipsis parentem quondam appellatum, si iure ageretur-potiorem, si armis-non invalidum vidissent. "(Piso said that Sentius)' soldiers will not fight when they see that Piso, whom they themselves once called 'father', (is) the stronger-if the verdict is by justice (and) not powerless-if by arms" (Ann. 2,80,2). ${ }^{10}$

+ Adjective (Attribute): Ann. 14,18,2 below.

Perf. Pass. (without esse): Ann. 3,33,4 above.

Inf. Perf. Act./Pass.: Predicate of AcI

${ }^{10}$ See also Ann. $6,40,2 ; 15,26,3-27,1$ above; $1,63,4 ; 3,16,4 ; 23,1$ (quondam modifies destinata
referring to Lepida); 4,25,1 below. 
(1) Valerium Asiaticum, bis consulem, fuisse quondam adulterum eius credidit "(Messalina) believed that Valerius Asiaticus, being twice consul, had formerly been Poppaea's adulterer" (Ann. 11,1,1).

(2) Praefatus ... maiorem ei patruum Cottam Messalinum esse, Memmio quondam Regulo nuptam "(Claudius) prefaced ... that Cotta Messalinus (was Lollia' s) great-uncle (and) she had once been married to Memmius Regulus" (Ann. 12,22,2).

Adjective

Attribute

Ego sicut inclutas quondam urbes igne caelesti flagrasse concesserim, ita halitu lacus infici terram, conrumpi superfusum spiritum ... reor

"I am ready to think on the one hand, that once famous cities were burnt up by fire from heaven, while on the other hand, I think that the soil is infected by the exhalation from the lake (and) the surrounding air is tainted" (Hist. 5,7,2).

See also Ann. 2,71,2 above; 14,18,2 below.

Predicate of Abl. Absol. in the Clause Preceding quondam

Ann. 3,60,3 below: in the comparison cl. quondam modifies the predicate of abl. absol. libero $^{11}$ mentioned in the main cl. (libero + quid ... mutaretve) in present.

\section{The Part of Speech Is not Explicit}

(1) Tandem apud promunturium Miseni consedit in villa, cui L. Lucullus quondam dominus. "(Tiberius) finally settled down on the promontory of Misenum, in a villa of which L. Lucullus (had) once (been its) master" (Ann. 6,50, 1).

The villa had belonged to L. Lucullus before Tiberius settled down on the promontory of Misenum. Consequently, the implied verb of the rel. cl. cui ... dominus is fuerat in p.q.p. (cf. Gerber and Greef 1877-1890, 2: 1347, s.v. quondam).

(2) Chattorum quondam populus. "(The Batavians were) formerly a tribe of the Chatti" (Ger. 29,1).

Quondam: Adjective

Noun

\footnotetext{
${ }^{11} \mathrm{~A}$ participle or adj. in $\mathrm{n}$. as predicate of abl. absol. with a sentence as its subject is abundant in Ann. Cf. L, Sh: 1057a, s.v. 1. liber, era, erum, adj. I. (ع); OLD: 1023c, s.v. liber ${ }^{1}$,era,-erum, adj. 10.c; Furneaux 1897: §19a.
} 
Is in maestitiam compositus et fidem suorum quondam militum invocans, ut eum in Syria aut Aegypto sisterent, orabat

"The pretender (to Nero), assuming an appearance of sorrow and appealing to the fidelity of his own former soldiers, begged (the captains) to land him in Syria or Egypt" (Hist. 2,9,2).

See also Ann. 16,10,4 below.

Apposition

(1) Hist. 2,68,4 below: quondam modifies the apposition ducis sui of Verginius Rufus (cf. the translation of Gerber and Greef 1877-1890, 2: 1347, s.v. quondam).

(2) Pars maeroris fuit, quod Iulia Drusi filia, quondam Neronis uxor, denupsit in domum Rubellii Blandi 'Part of (Rome's) sorrow was for Julia, Drusus' daughter (and) formerly Nero's wife, married (now) into the family of Rubellius Blandus" (Ann. 6,27,1).

(3) Laelius Balbus Acutiam, P. Vitellii quondam uxorem, maiestatis postulaverat "Laelius Balbus had accused Acutia, the former wife of P. Vitellius, of treason" (Ann. 6,47,1). ${ }^{\mathbf{1 2}}$

A Substantivized Adjective in Apposition

Hist. 1,46,1 above: quondam modifies e manipularibus, an apposition of Plotius Firmus.

Adjective: Attribute

(1) Scripsit Tiberio ... multis nationibus clarissimum quondam regem ad se vocantibus Romanam amicitiam praetulisse

"(Maroboduus) wrote to Tiberius ... that he had preferred the Roman friendship, although many nations had invited to them the king once so glorious" (Ann. 2,63,1).

(2) Mox compertum a transfugis ... quadringentorum manum occupata Cruptorigis quondam stipendiari( $i$ villa ... mutuis ictibus procubuisse

"Later it was reported by deserters ... that a detachment of four hundred (Romans), after occupying the villa of Cruptorix, a former mercenary ... had fallen by mutual blows" (Ann. 4,73,4).

See also Ann. 4,14,3 above.

Noun + Adjective (Attribute)

Nihil aliud prolocutus quam 'beatos quondam duces Romanos'

"(Corbulo) made no utterance except 'happy (were) the Roman commanders of old!'

"(Ann. 11,20,1).

\footnotetext{
${ }^{12}$ See also Hist. 3,47,1 (quondam modifies praefectus, an apposition of the $\mathrm{S}$ mancipium. Cf. Wolf 1926: 58); Ann. 6,37,3; 16,17,2 above; Ann. 3,69,5; 4,27,1; 31,3; 6,7,2 below.
} 
Table 4. The Part of Speech Modified by Quondam

\begin{tabular}{|c|c|c|c|}
\hline The Modified Part of Speech & References & Cases & Total \\
\hline $\begin{array}{l}\text { Quondam } \text {-adv. } \\
\text { Finite verb: p.q.p. } \\
\text { In idiom } \\
\text { In the following cl. }\end{array}$ & $\begin{array}{l}\text { Hist. } 3,43,1 ; 5,4,2 ; \text { Ann. } 1,8,5 ; 12,4 ; 54,1 ; \\
77,3 ; 2,27,2 ; 12,39,2 \\
\text { Ann. } 15,71,4 \\
\text { Ann. } 12,56,1\end{array}$ & $\begin{array}{l}8 \\
1 \\
1\end{array}$ & \\
\hline $\begin{array}{l}\text { Perf. } \\
\text { In the following cl. }\end{array}$ & $\begin{array}{l}\text { Ann. } 3,56,4 \\
\text { Ann. } 16,22,2\end{array}$ & $\begin{array}{l}1 \\
1\end{array}$ & \\
\hline Fut. II & Ann. 3,6,2 & 1 & 13 \\
\hline $\begin{array}{l}\text { Participia } \\
\text { P.P.P.: replaces a cl. } \\
\text { + adj. (attribute) } \\
\text { Perf. pass. (without esse) }\end{array}$ & $\begin{array}{l}\text { Ann. } 1,9,1 ; 63,4 ; 2,80,2 ; 3,16,4 ; 23,1 ; 4,25,1 ; \\
6,40,2 ; 15,26,3-27,1 \\
\text { Ann. } 14,18,2 \\
\text { Ann. } 3,33,4\end{array}$ & $\begin{array}{l}8 \\
1 \\
1\end{array}$ & \\
\hline P.P.A. (attrib.) + adj. (attrib.) & Ann. 2,71,2 & 1 & 11 \\
\hline $\begin{array}{l}\text { Inf. perf. act./pass. } \\
\text { predicate of AcI }\end{array}$ & Ann. $2,60,3 ; 3,34,4 ; 11,1,1 ; 12,22,2 ; 13,55,2$ & 5 & 5 \\
\hline $\begin{array}{l}\text { Adjective: attribute } \\
\text { Predicate of abl. absol. in the } \\
\text { preceding cl. }\end{array}$ & $\begin{array}{l}\text { Hist. 5,7,2; Ann. 2,71,2; 14,18,2 } \\
\text { Ann. 3,60,3 }\end{array}$ & $\begin{array}{l}3 \\
1\end{array}$ & 4 \\
\hline Is not explicit & Ger. 29,1; Ann. 6,50,1 & 2 & 2 \\
\hline Quondam-adj.: Noun & Hist. $2,9,2 ;$ Ann. 16,10,4 & 2 & \\
\hline Apposition & $\begin{array}{l}\text { Hist. } 2,68,4 ; 3,47,1 ; \text { Ann. 3,69,5; 4,27,1; 31,3; } \\
6,7,2 ; 27,1 ; 37,3 ; 47,1 ; 16,17,2\end{array}$ & 10 & \\
\hline $\begin{array}{l}\text { Subst. adj. in } \\
\text { apposition }\end{array}$ & Hist. $1,46,1$ & 1 & \\
\hline Adj. (attribute) & Ann. $2,63,1 ; 4,14,3 ; 73,4$ & 3 & \\
\hline Noun + adj. (attribute) & Ann. $11,20,1$ & 1 & 17 \\
\hline
\end{tabular}

\section{The Position of quondam in Relation to the Part of Speech Modified by It}

The typical word order in a cl./sentence is $\mathrm{S}$ (+ its modifiers)-OID/OD-V (+ its modifiers). Temporal/negative advs. and temporal phrases (paulo ante, iam diu, etc.) usually precede the modified element. Exceptions to these rules for variety, emphasis, etc. are generally used in classical Latin prose (chiefly in rhetorical passages and poetry) by: 1) Metathesis of words: the adv. occurs after its modified part of speech (apart from monosyllabic words such as non, vel), the verb precedes its subject; 2) Hyperbaton between the adv. and the modified part of speech; 3) Proximity of similar words (modo ... nunc) or opposite ones (ölim ... mox).

The position of quondam in relation to the part of speech modified by it was examined by linguistic/stylistic means and contexts (where some message is to be highlighted, word order, anaphora, a chiastic/parallel structure mainly when two pairs of words are contrasted; cf. Fanetti 1978-79). The interval between quondam 
and its modified element was calculated, inter alia, by number of words (usually ranges from one to three words with exceptions consisting of more words). On the other hand, it is not always possible to find any explanation or an unequivocal explanation on the adv.'s position, due to differences in content/style between the oratorical/historical works of Tacitus. Latin word order is not fixed in the sentence, despite its freedom. Likewise, the opinions on the adv.'s position are not uniform. ${ }^{13}$

Quondam: adverb. A. Its prevalent position is before its modified part of speech-19x: first position-6x; second placement-1x; third position or further removed-12x. B. After it-7x: first position-6x; second placement-1x. C. Two positions-5x: 1) First position before +1.1 ) Second placement before-1x; 1.2) Third position or further removed before-2x; 2) Second position before +2.1 ) Second place after-1x; 2.2) Third position or further removed before-1x.

Quondam: adjective. A. Before its modified element-8x: first position-4x; second placement-3x; third position or further removed-1x. B. After it: first position-4x. C. Two positions-5x: 1) First + second position before-4x; 2) First position after + third place before- $1 \mathrm{x}$.

Quondam is not placed at the end of a cl./sentence (for references see table 5 below).

\section{Quondam: Adverb}

\section{Before the Modified Part of Speech}

First Position

(1) Sue abstinent memoria cladis, quod ipsos scabies quondam turpaverat, cui id animal obnoxium "(The Jews) abstain from (eating) pork in recollection of a plague, for the scab to which this animal (is) liable, formerly infected themselves" (Hist. 5,4,2).

The causal cl. quod ... turpaverat deals with the subject scabies, which is also the antecedent of the following rel. cl. cui ... obnoxium. However, the OD ipsos precedes the subject scabies, in order to juxtapose ipsos to the Jews mentioned before. For these reasons, in the causal cl. quondam + its modified verb turpaverat are postponed to its end with the order causal conj. - OD - S - temporal adv. modified V.

(2) Valuit tamen intercessio, quia divus Augustus immunes verberum histriones quondam responderat. "The intervention was nevertheless effective, for the divine Augustus had once pronounced that the actors (were) immune from floggings" (Ann. 1,77,3).

In the causal cl. (quia ... responderat) quondam is embedded between the AcI immunes verberum ${ }^{14}$ histriones (governed by responderat) and its modified verb responderat. By this word order is emphasized the AcI in the past.

\footnotetext{
${ }^{13}$ See Booth 1923: IX; Marouzeau 1948: 155-61; 1949: 11-33, Kühner and Stegmann 1962, 2/2: §246, Bos 1967: 117, Pinkster 1972; 1990: 163-188; de Jong 1991; Elerick 1994; Devine and Stephens 2006, Hoffmann 2010.

${ }^{14}$ For immunis + gen. see L, Sh: 895, s.v. immunis, e, adj., II. ( $\alpha$ ); OLD: 839a, s.v. immunis, e, adj., 4.
} 
(3) Adfertur Numidas apud castellum semirutum, ab ipsis quondam incensum, consedisse "It was reported that the Numidians had encamped in a half-ruined fortress, which had formerly been burnt by them" (Ann. 4,25,1).

The attribute cl. $a b$... incensum of castellum is introduced by an abl. instr. $a b$ ipsis, because it refers to the Numidians mentioned before. For this reason, quondam is not placed in second position before the modified incensum (replacing a rel. cl. of castellum), but in first position before it, while in the attribute cl. the order is abl. instr. - temporal adv. - modified P.P.P.

Cf. Ann. 2,80,2 above: in order to juxtapose the abl. instr. ab ipsis to militibus mentioned before $u b i \mathrm{cl}$. and also the praedicativum parentem to Pisonem, quondam appears before the modified appellatum of the attribute cl. (ab ipsis ... appellatum) referring to Pisonem in AcI (governed by vidissent).

(4) Ann. 15,26,3-27,1 above: in the attribute cl. L. .. penetratum of iter the adv. is embedded between dat. agentis L. Lucullo and the modified penetratum (referring to the internal acc. iter; see OLD: 1324a, s.v. penetro, 2.a). Quondam in first position after penetratum (sc. penetratum quondam apertis) can be interpreted as modifying the predicate apertis of abl. absol.

(5) Ann. 6,40,2 above: quondam-tunc before the modified elements potitusreus (referring to Tigranes) emphasize the semantic parallel contrast between the following multiple parts: formerly Tigranes was a ruler and later became a defendant. Accordingly, Armenia in abl. loci governed by potitus ${ }^{\mathbf{1 5}}$ appears before quondam and not near potitus: quondam potitus

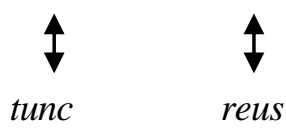

Second Position

Honos apud praetorianos, quorum quondam tribunus fuerat

"(Valerius Paulinus was held in) honor by the Praetorian (soldiers), whose tribune he had formerly been" (Hist. 3,43,1).

The apposition tribunus of the $\mathrm{S}$ Valerius Paulinus is highlighted by its occurrence between quondam and the modified verb fuerat. Cf. Ann. 1,12,4; 2,27,2 above.

Third Position or Further Removed

(1) Ann. 1,8,5 above: in the comparison cl. (ut ... turbassent) turbassent is emphasized by its modifier quondam + an abl. modi nimiis studiis occurring before it. The OD funus divi Iulii of the comparison cl. is compared to the OD Augustum of the main cl. ita Augustum (without repetition of funus).

(2) Ann. 3,56,4 above: the subject ipse (viz. Tiberius) of the rel. cl. (qua ipse ... vocatus sit) is in proximity to the rel. pron. qua, in order to juxtapose ipse to eamque aetatem, which refers to Tiberius' age. An abl. instr. a divo Augusto +

\footnotetext{
${ }^{15}$ See L, Sh: 1409 a, s.v. 1. potior, II. (y); OLD: 1418b, s.v. potior $^{1}$, 5. a.
} 
gndv. of purpose ad capessendum hoc munus concern Tiberius's age and reinforce the modified verb vocatus sit with their insertion between quondam and vocatus sit. Cf. Ann. 1,54,1 above: instituerat is emphasized by quondam + gndv. in dat. of purpose retinendis Sabinorum sacris.

(3) Ann. 3,33,4 above: quondam occurs between both adjs. Oppiis + aliisque of legibus. In this manner, the modified verb constrictae by quondam is also emphasized by: 1) An abl. instr. Oppiis aliisque legibus, explaining by which the women's orders were formerly restrained; 2) A parallel contrast (adv.-modified V) between quae ... constrictae and nunc ... regerent (with repetition of iam instead of the anaphora by nunc): quondam constrictae

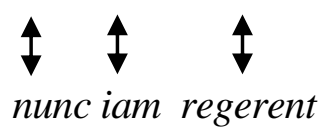

(4) Angustus is trames vastas inter paludes et quondam a L. Domitio aggeratus_"This (was) a narrow causeway amid vast swamps and which had formerly been constructed by L. Domitius" (Ann. 1,63,4).

The attribute cl. (quondam a L. Domitio aggeratus) of trames describes the place, on which the narrow causeway was located. An abl. agentis a L. Domitio between quondam and aggeratus draws attention by whom the narrow causeway had formerly been constructed. Consequently, the order is temporal adv. - abl. agentis - modified P.P.P. (aggeratus replacing a rel. cl. of trames).

(5) Referendum iam animum ad firmitudinem, ut quondam divus Iulius amissa unica filia, ut divus Augustus ereptis nepotibus abstruserint tristitiam

"Now (the Romans') spirits should be restored to fortitude, as formerly the divine Julius (Caesar) after the loss of his only daughter (and) as the divine Augustus when bereaved of his grandchildren had set aside (their) sorrow" (Ann. 3,6,2).

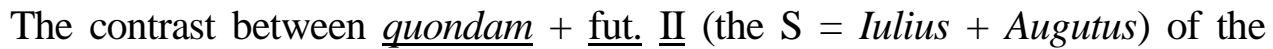
comparison cl. ut quondam ... tristitiam and iam + gerundive (the $\mathrm{S}=$ the Romans) of the main cl. referendum ... firmitudinem is strengthened by a chiastic order (modified gndv.-adv./adv.-modified V). The OD tristitiam occurs after abstruserint, in order to avoid a long hyperbaton between abstruserint and its subjects. A parallel order (conj.-S-abl. absol.) between both multiple parts $u t$... filia; ut ... nepotibus of the comparison cl. highlights when Caesar and Augustus had set aside their sorrow:

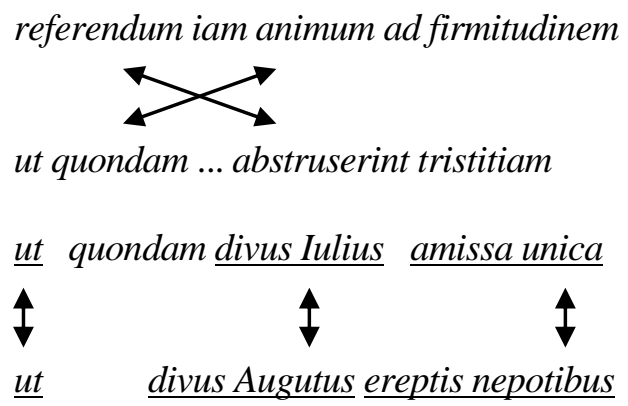


(6) 'Quondam divo Augusto parenti tuo probatus ... salutem infelicis filii rogo' "I who formerly won the esteem of the divine Augustus your father ... beg (you) for the safety of my unfortunate son' "(Ann. 3,16,4).

In the attribute cl. quondam ... probatus of the subject Piso quondam is in third position and further removed before the modified probatus, due to dat. agentis (+ its adj. and apposition) divo Augusto parenti tuo governed by probatus (see, e.g., OLD: 1404c, s.v. probatus,-a,-um, 2.b).

(7) Ann. 13,55,2 above): The predicate fuisse of AcI (after Boiocalus' report) is modified by three temporal advs.: quondam, mox and post. Since quondam is anterior to mox and post, it is placed before them and is in third position and further removed before fuisse. In the following three multiple parts occur chiastic/parallel arrangements between the advs. and the modifiers in gen. of the subject ea arva:

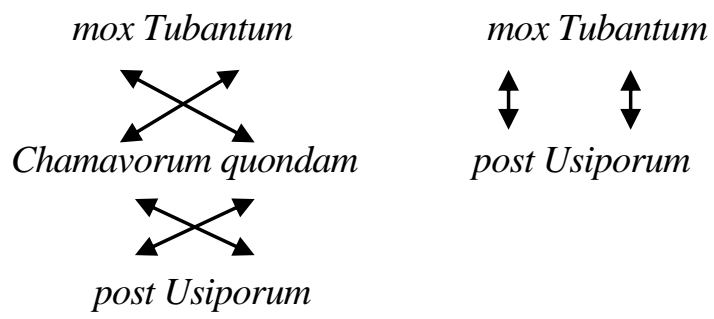

(8) Ann. 16,22,2 above): loquitur (its $\mathrm{S}=$ civitas) is mentioned only in the main cl. ita ... loquitur in present, but is modified by quondam and nunc. This phenomenon is expressed by: 1) A parallel contrast (adv.-multiple OD) between the comparison cl. and its main cl.; 2) Ita (in correlation to $u t$ ) before nunc:

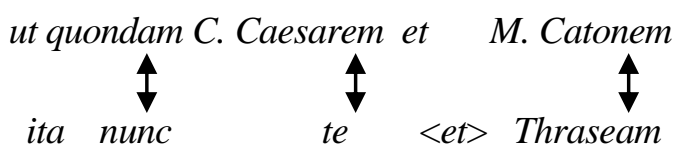

Stylistically, loquor can not be placed in the comparison cl. in the past tense, due to inquit in perfect (introducing Capito's direct speech) with the same meaning of loquitur.

(9) Lacu in ipso navale proelium adornatur, ut quondam Augustus structo cir $<c a>$ Tiberim stagno, sed levibus navigiis et minore copia ediderat. "A naval battle was arranged on the lake (Fucinus) itself, just as Augustus had formerly exhibited in a pool, which had been constructed near the Tiber, but with light vessels and a smaller force" (Ann. 12,56,1).

Adverbial exprs. in abl./acc. usually precede the verb. In this example, abl. loci/instr. + acc. of place (structo ... copia referring to lacu of the main cl. lacu ... adornatur) are embedded between the subject Augustus and the modified verb ediderat of the comparison cl. ut quondam ... ediderat. This is in order to point out the place structo circa Tiberim stagno and the instrument levibus navigiis et minore copia, by which Augustus had formerly exhibited the naval battle. 


\section{After the Modified Part of Speech}

First Position

(1) Ann. 1,9,1 above: quondam is embedded between the modified accepti (referring to imperii) and imperii. The adv. after the whole phrase accepti imperii (i.e. dies accepti imperii quondam princeps et vitae supremus) may modify an omitted copula esse of the multiple predicate nouns princeps + vitae supremus of dies. Accordingly, in the attribute cl. accepti quondam imperii of dies the order is modified P.P.P. - temporal adv. - gen. of the $\mathrm{S}$ dies.

(2) Quirinio clamitarent, cuius senectae atque orbitati et obscurissimae domui destinata quondam uxor L. Caesari ac divo Augusto nurus dederetur

"(The crowd) repeatedly shouted against Quirinius, to whose old age, childlessness and most obscure family, (Lepida), once destined as wife of L. Caesar and daughter-in-law of the divine Augustus, was surrendered" (Ann. 3,23, $1)$.

In the rel. cl. (cuius ... dederetur) quondam occurs between the modified destinata (referring to Lepida and governs dat. senectae ... domui [with polysyndeton between the datives]) and both multiple chiastic appositions (nom.-dat./dat.nom.) of Lepida. By this word order is emphasized that Lepida was destined in the past as wife of L. Caesar and also as daughter-in-law of Augustus. Quondam after both appositions (sc. destinata uxor L. Caesari ac divo Augusto nurus quondam dederetur) will modify, from a preliminary reading, dederetur:

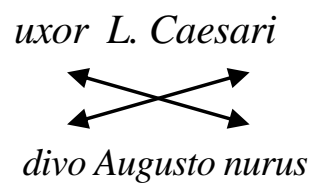

(3) Ann. 11,1,1 above: in the AcI cl. (governed by credidit; its S = Messalina) the apposition adulterum eius (eius refers to Poppaea) of the $\mathrm{S}$ Valerius Asiaticus is also made salient by placing quondam between the modified predicate fuisse and the apposition. Quondam in third position after fuisse (i.e. fuisse ... quondam credidit) may modify credidit.

(4) 'Placuisse quondam Oppias leges, sic temporibus rei publicae postulantibus; remissum aliquid postea et mitigatum, quia expedierit' "'The Oppian laws were formerly accepted, since the circumstances of the state so required (them. But) subsequently there were some relaxation and mitigation, since it was expedient' "' (Ann. 3,34,4).

In the AcI cl. placuisse ... leges (after Valerius Messalina's reply) the modified predicate placuisse by quondam is emphasized by metathesis of words: it introduces the AcI cl. and occurs before quondam + the S Oppias leges. The same word order is valid in Ann. 2,60,3 above.

(5) Hist. 5,7,2 above: quondam appears after the modified adj. inclutas of the $\mathrm{S}$ urbes in AcI (governed by reor) and not before it (i.e. quondam inclutas ... flagrasse), since it may modify flagrasse. An abl. instr. igne caelesti between 
inclutas quondam urbes and flagrasse highlights by which once famous cities burnt up. In this manner is emphasized a chiastic contrast (S-inf. perf./inf. praes.S) between the comparison cl. sicut ... concesserim and its main cl. ita ... spiritum (for ut/sicut ... ita see, e.g., OLD: 973a, s.v. ita, adv., 4):

conrumpi spiritum

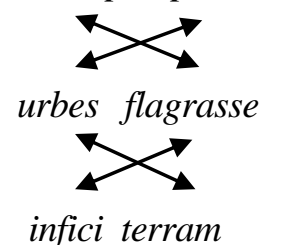

Second Position

Libero, ut quondam, quid firmaret mutaretve

"(The senate) is free, as formerly, regarding what to confirm or change" (Ann. $3,60,3)$.

The predicate libero of the abl. absol. precedes its subject cl. quid firmaret mutaretve (see $\mathrm{n} .11$ above). In order to juxtapose the modified predicate libero of the main cl. to quondam (in the past), the comparison cl. ut quondam is embedded in its main cl. libero + quid ... mutaretve.

First Position before +

Second Position before

Ann. 15,71,4 above: the adv. is placed before the OID matrimonio and not vice versa, since it modifies the idiom matrimonio tenuerat $(\mathrm{OID}+\mathrm{V}$; its $\mathrm{S}=$ Rufrius Crispinus).

Third Position and Further Removed before

(1) Ann. 2,71,2 above: quondam is placed before both modified attributes florentem + superstitem (with the coord. conj. et between them) of the subject Germanicus in AcI (after inlacrimabunt; ${ }^{\mathbf{1 6}}$ the predicate $=$ cecidisse). On ground of gen. obiect. tot bellorum before superstitem, quondam is in third position before the second modified attribute superstitem.

(2) Missum disceptatorem a Claudio agrorum, quos regis Apionis quondam avitos et populo Romano cum regno relictos proximus quisque possessor invaserant 17 "(Acilius Strabo) was sent by Claudius as an arbitrator of the estates,

\footnotetext{
${ }^{16}$ For the AcI construction after inlacrimo see, e.g., OLD: 826b, s.v. illacrimo; Goodyear 1981: 413.

${ }^{17}$ For the reading invaserat in sg. see Koestermann 1971: 305, Heubner 1994: 318. According to Woodcock (1992: 107), invaserant is in pl. (see also Fisher 1906: 313) after quisque by constructio ad sensum.
} 
which once the ancestral estate of the King Apion and had been left along with his kingdom, any of the neighboring proprietors had invaded" (Ann. 14,18,2).

Proximus ... invaserant $(\mathrm{S}+\mathrm{V})$ of the rel. cl. quos ... invaserant are postponed to its end, in order to avoid a long hyperbaton between both modified elements by quondam (sc. adj. avitos + P.P.P. relictos replaces a rel. cl. of quos) and their OD quos. Quondam is in third position and further removed before relictos due to dat. + abl. sociat. (populo ... cum regno) before relictos.

Second Position before +

Second Placement after

Ann. 12,22,2 above: in the AcI cl. Memmio ... nuptam (after Claudius remarks) quondam is in second position after esse + second place before nuptam, which are modified by it (the $S=$ Lollia): 1) In order that the predicate nuptam of AcI in inf. perf. pass. will be near esse mentioned in the preceding AcI; 2) Due to dat. Memmio Regulo governed by nubo.

Third Position and Further Removed before

Accendebat vulgata imper<atoris> Romani vox, ut quondam Sugambri excisi aut in Gallias traiecti forent, ita Silurum nomen penitus exstinguendum

"The rumoured saying of the Roman commander infariated (the Silures) that, as formerly the Sugambrians had been exterminated or transferred to the Gallic (provinces), so the Silures' name ought to be extinguished completely" (Ann. 12,39, 2).

In the comparison cl. (ut ... forent) forent refers to both modified verbs excisi + traiecti by quondam in O.O. governed by vox. Their subject Sugambri is placed before them, whereas the acc. direct. in Gallias refers only to traiecti forent and occurs before it. Consequently, quondam is in second position before excisi + in third position before traiecti forent.

\section{Quondam: Adjective}

\section{Before the Modified Part of Speech \\ First Position}

(1) Ann. 4,73,4 above: the adv. occurs before the modified adj. stipendiarii of Cruptorigis and not before the whole phrase Cruptorigis stipendiarii (viz. occupata quondam Cruptorigis stipendiarii villa), since it will modify at first sight the predicate occupata of the abl. absol. For this reason, Cruptorigis precedes quondam + the adj. stipendiarii.

(2) Neve consulatus sui quondam collegam dederet liberto ... clamitabat

"(Poppaea) repeatedly cried out that (Nero) would not surrender his former colleague of his own consulship to a freedman" (Ann. 16,10,4). 
In the indirect command cl. neve ... liberto (after clamitabat) quondam is embedded between the reflex. pron. sui (in gen. obiect.) of Nero and its modified OD collegam, in order to juxtapose sui quondam collegam to Nero mentioned before. Consequntly, the OD collegam precedes the OID liberto in dat. (governed by dederet; see $O L D, 496 \mathrm{~b}$, s.v. dedo, 1.b). Consulatus, an attribute in gen. to sui quondam collegam, occurs before it with the typical word order in Latin.

For a similar word order see Hist. 2,9,2 above.

\section{Second Position}

Q. Servaeus posthac Minucius Thermus inducti, Servaeus praetura functus et quondam Germanici comes

"Afterwards Q. Servaeus (and) Minucius Thermus were brought to trial. Servaeus having held the praetorship and formerly a companion of Germanicus" (Ann. 6,7,2).

Quondam, which modifies the nucleus comes of the apposition Germanici comes (its $\mathrm{S}=\mathrm{Q}$. Servaeus), is in second position before it due to the modifier in gen. Germanici before comes.

See also Ann. 6,27,1; 47,1 above.

Third Position

Auctor tumultus T. Curtisius, quondam praetoriae cohortis miles

"The instigator of the revolt (was) T. Curtisius, a former soldier of the praetorian guard" (Ann. 4,27,1).

Quondam modifies the nucleus miles of the apposition praetoriae cohortis miles (its $\mathrm{S}=\mathrm{T}$. Curtisius). If it is placed in first position before miles (viz. praetoriae cohortis quondam miles), only miles will be an apposition of the $\mathrm{S}$, while praetoriae cohortis alone will be an attribute in gen. of the subject (mainly in an unpunctuated text) as follows: "T. Curtisius of the praetorian cohort, a former soldier". The same phenomenon is valid in Hist. 3,47,1 above.

After the Modified Element

First Placement

(1) Ann. 4,14,3 above: the subject ludicrum of AcI (after Tiberius report) consists of two descriptions: 1) The modified adj. Oscum by quondam; 2) Levissimae oblectationis $(\operatorname{adj} .+\mathrm{N})$ in gen. qualitatis. Quondam is in first position after Oscum and not in second one after it (i.e. Oscum ludicrum quondam levissimae), because it will apparently modify the adj. levissimae.

(2) P. Suillium, quaestorem quondam Germanici ... amovendum in insulam censuit "(Tiberius) held that P. Suillius, a former quaestor of Germanicus ... ought to be banished to an island" (Ann. 4,31,3).

The nucleus quaestorem of the apposition quaestorem Germanici (its $\mathrm{S}=$ Suillius in AcI governed by censuit) is emphasized by its occurrence before 
quondam and before its modifier in gen. Germanici (contrary to the word order in Latin). Cf. Ann. 2,63,1 above.

(3) Hist. 1,46,1 above: quondam is placed after the modified apposition $e$ manipularibus of the OD Plotius Firmus by metathesis of words. In this manner is made salient a chiastic contrast (modified apposition-anterior adv./posterior adv.modified apposition) between both multiple parts ( $e$... quondam; tum ... praepositum) of the OD:

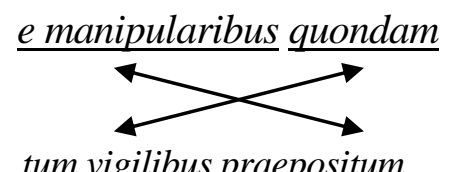

tum vigilibus praepositum

First + Second Placement before

(1) Ann. 16,17,2 above: the occurrence of quondam before the modified apposition praefectus praetorii ( $\mathrm{N}+$ subst. adj.) of the subject hic emphasizes the parallel contrast (adv.-modified P.P.P. [replacing a rel. cl. of hic, sc. Rufrius Crispinus]) between both multiple parts nam ... donatus and ac ... exactus, sc. Crispinus was formerly a commander and had been rewarded with consular insignia, but later was exiled:

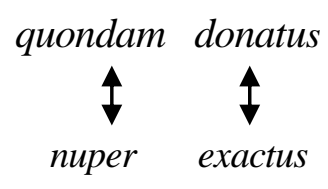

(2) Aegre tamen cohibiti qui exitium consularis et quondam ducis sui flagitabant "Yet hardly were restrained (the troops), who demanded the execution of the consular and their former own commander (Verginius)" (Hist. 2,68,4).

In the rel. cl. qui ... flagitabant two multiple appositions refer to Verginius Rufus: consularis and ducis sui. Due to the occurrence of quondam after et, it modifies only ducis sui. If it is placed after ducis sui (i.e. ducis sui quondam flagitabant), it will modify, as it were, flagitabant.

(3) Darent Iuniae familiae et viro quondam ordinis eiusdem, ut Cythnum potius concederet "(Tiberius added) that to the Junian family and to (Silanus) a man formerly of the same rank should be allowed to retire to Cythnus instead" (Ann. 3,69,5).

Quondam ordinis eiusdem refers to the senatorial rank of Silanus, which he lost in a sentence of exile (see L, Sh: 1278a, s.v. ordo, II. C.; Woodman and Martin 1996: 471). Quondam before the modified ordinis eiusdem in gen. qualitatis emphasizes the character of viro (sc. Silanus).

(4) Ann. 11,20,1 above: quondam appears before the modified duces Romanos ( $\mathrm{N}+$ its adj.) in AcI (governed by prolocutus; its $\mathrm{S}=$ Corbulo). The adv. in second position before duces (sc. ... quondam beatos duces Romanos) will modify, from a preliminary reading, the predicate beatos (esse) of AcI as follows: "happy (were) once the Roman commanders". 
First Position after + Third Position and Further Removed before

Ann. 6,37,3 above: quondam emphasizes the first modified apposition exul of Ornospades by reversing its ordinary position. A temporal cl. (cum Delmaticum bellum conficeret) between the dat. Tiberio (governed by auxiliator) and the second modified apposition haud inglorius auxiliator (an adj. in litotes) of Ornospades indicates when Ornospades was a glorious adjuvant of Tiberius. From the abovementioned reasons, quondam is placed in first position after exul + in third position and further removed before haud inglorius auxiliator.

Table 5. The Position of Quondam in Relation to Its Modified Part of Speech

\begin{tabular}{|c|c|c|c|}
\hline Quondam: adv. & References & Cases & Total \\
\hline Before: first position & $\begin{array}{l}\text { Hist. 5,4,2; Ann. 1,77,3; 2,80,2; 4,25,1; 6,40,2; } \\
\text { 15,26,3-27,1 }\end{array}$ & 6 & \\
\hline Second placement & Hist. 3,43,1 & 1 & \\
\hline $\begin{array}{l}\text { Third position or } \\
\text { further removed place }\end{array}$ & $\begin{array}{l}\text { Ann. } 1,8,5 ; 12,4 ; 54,1 ; 63,4 ; 2,27,2 ; 3,6,2 ; 16,4 ; \\
33,4 ; 56,4 ; 12,56,1 ; 13,55,2 ; 16,22,2\end{array}$ & 12 & 19 \\
\hline After: first position & Hist. 5,7,2; Ann. 1,9,1; 2,60,3; 3,23,1; 34,4; 11,1,1 & 6 & \\
\hline Second placement & Ann. 3,60,3 & 1 & 7 \\
\hline $\begin{array}{l}\text { First position before }+ \\
\text { Second place before }\end{array}$ & Ann. $15,71,4$ & 1 & \\
\hline Third position before & Ann. $2,71,2 ; 14,18,2$ & 2 & 3 \\
\hline $\begin{array}{l}\text { Second place before }+ \\
\text { Second position after }\end{array}$ & Ann. $12,22,2$ & 1 & \\
\hline Third position before & Ann. 12,39,2 & 1 & 2 \\
\hline $\begin{array}{l}\text { Quondam: } \underset{\text { adj. }}{\text { Before: first position }} \\
\text { B. }\end{array}$ & Hist. $2,9,2 ;$ Ann. 4,73,4; 6,47,1; 16,10,4 & 4 & \\
\hline Second placement & Hist. 3,47,1; Ann. 6,7,2; 27,1 & 3 & \\
\hline Third position & Ann. 4,27,1 & 1 & 8 \\
\hline After: first position & Hist. 1,46,1; Ann. 2,63,1; 4,14,3; 31,3 & 4 & 4 \\
\hline $\begin{array}{l}\text { First }+ \text { second place } \\
\text { before }\end{array}$ & Hist. 2,68,4; Ann. 3,69,5; 11,20,1; 16,17,2 & 4 & 4 \\
\hline $\begin{array}{l}\text { First position after }+ \\
\text { third placement before }\end{array}$ & Ann. 6,37,3 & 1 & 1 \\
\hline
\end{tabular}

\section{A Comparison of quondam as an Adv. and an Adj. between Tacitus' Treatises}

A concluding comparison of quondam as an adv. and an adj. between Tacitus' treatises yielded mainly different features due to contents and author's style in each book (see Table 6 below; for references see Tables 1-5 above). 
Table 6. A Comparison of quondam as an Adv. and Adj. between Tacitus' Books

\begin{tabular}{|l|c|c|c|c|c|c|c|}
\hline \multirow{2}{*}{ The Features } & \multicolumn{3}{|c|}{ Adv. } & \multicolumn{3}{c|}{ Adj. } & \multirow{2}{*}{ Total } \\
\cline { 2 - 8 } & Ger. & Hist & Ann. & Ger. & Hist. & Ann. & \\
\hline 1 Distribution & 1 & 3 & 29 & - & 4 & 13 & 50 \\
\hline 2 Meanings: & & & & & & & \\
"Formerly, in the past" & 1 & 3 & 29 & - & - & - & 33 \\
"Former, previous" & - & - & - & - & 4 & 13 & 17 \\
\hline 3 A contrasting temporal adv. & - & - & 4 & - & 1 & 3 & 8 \\
Posterior adv. & - & - & 4 & - & - & - & 4 \\
Present adv. & 1 & 3 & 21 & - & 3 & 10 & 38 \\
Lack of a temporal adv. & & & & & & & \\
\hline 4 The modified part of speech & - & 2 & 11 & - & - & - & 13 \\
Finite verb & - & - & 11 & - & - & - & 11 \\
Participia & & & & & & & 5 \\
Inf. perf. act./pass.: predicate of AcI & - & - & 5 & - & - & - & 5 \\
Adj. & - & 1 & 3 & - & - & 3 & 7 \\
Noun/apposition & - & - & - & - & 4 & 10 & 14 \\
Is explicit & - & 3 & 30 & - & 4 & 13 & 50 \\
Is not explicit & 1 & - & 1 & - & - & - & 2 \\
\hline 5 The adverb's position & & & & & & & \\
Before: first/second/third position & - & 2 & 17 & - & 2 & 6 & 27 \\
\hline After: first/second position & - & 1 & 6 & - & 1 & 3 & 11 \\
\hline First position before + & & & & & & & \multirow{2}{*}{7} \\
Second/third position before & - & - & 3 & - & 1 & 3 & 7 \\
\hline Second placement before + & & & & & & & \\
Second position after & - & - & 1 & - & - & - & 1 \\
Third position before & - & - & 1 & - & - & - & 1 \\
\hline First position after + third place before & - & - & - & - & - & 1 & 1 \\
\hline
\end{tabular}

\section{Conclusions}

Quondam occurs in Ann., Hist. and Ger. It is not documented in Ag. and Dial. It is used as a temporal adv. "formerly, in the past, once" and as an adj./quasi-adj. in a temporal sense "former, previous". In some examples quondam occurs in proximity to a contrasting temporal adv. (mostly posterior adv. to quondam) and mainly without it.

The part of speech modified by quondam: 1) It is explicit (except for 2x); 2) It is mostly mentioned in the cl., in which quondam is included. In a few cases it occurs in the cl. precedes quondam or follows it; 3) The modified element is mainly a finite verb in the past tenses (p.q.p., perf., fut. II), participia or an apposition. Sometimes it is an adj., inf. or a noun; 4) In a few cases quondam modifies more than one part of speech in a cl./sentence.

The prevalent position of quondam is before the modified part of speech (first/second/third position or further removed) and sometimes after it (first/second 
position). In some instances quondam has two positions concerning the modified part of speech.

A concluding comparison of quondam as an adv. and an adj. between Tacitus' treatises in the points indicated above yielded mostly different features.

\section{References}

Ash R (2018) The Annals of Tacitus, Books XV. Cambridge Greek and Latin Classics. Cambridge: Cambridge University Press.

Blackman DR, Betts GG (1986) A Concordance to Tacitus. Concordantia Tacitea 2. Hildesheim, Zurich \& New York: Olms-Weidmann.

Booth BE (1923) The Collocation of the Adverb of Degree in Roman Comedy and Cato. Doctoral Dissertation, University of Chicago. Chicago.

Bos GE (1967) L'adverbe en Latin. Tentative de classification structurale. Bulletin de la Société de linguistique de Paris 62: 106-122.

Devine AM, Stephen LD (2006) Latin Word Order: Structured Meaning and Information. Oxford: Oxford University Press.

Elerick C (1994) How Latin Word Order Works. In G Calboli (ed.), 99-117. Papers on Grammar IV. Rome: Herder.

Fanetti D (1978-79) Il Chiasmo nell' Agricola di Tacito. Museum criticum 13-14: 389400.

Fisher CD (1906) Cornelii Taciti Annalium. Ab Excessu Divi Augusti Libri. Oxford Classical Texts. Oxford: Oxford University Press.

Fisher CD (1911) Cornelii Taciti Historiarum Libri. Oxford Classical Texts. Oxford: Oxford University Press.

Francis ED (1973) Particularum quarundam varietas: prae and pro. In T Cole, D Ross (eds), Studies in Latin Language and Literature, 1-59. Yale Classical Studies 23. Cambridge: Cambridge University Press.

Furneaux H (1897) Cornelii Taciti Annalium, Libri I-IV (2 $2^{\text {nd }}$ edn). Oxford: Oxford University Press (repr. 1938).

Gerber A, Greef A (1877-1890) Lexicon Taciteum 2. Leipzig: BG Teubner (repr. Hildesheim: G. Olms, 1962).

Goodyear FRD (1972) The Annals of Tacitus I: Annals 1, 1-54. Cambridge Classical Texts and Commentaries 15. Cambridge (repr. 2004).

Goodyear FRD (1981) The Annals of Tacitus II: Annals 1, 55-81 and Annals 2. Cambridge Classical Texts and Commentaries 23. Cambridge: Cambridge University Press (repr. 2004).

Heubner H (1978) P. Cornelii Taciti Libri Qui Supersunt 2/1. Historiarum Libri. Bibliotheca Scriptorum Graecorum et Romanorum Teubneriana. Stuttgart: BG Teubner.

Heubner H (1994) P. Cornelii Taciti Libri Qui Supersunt 1. Ab Excessu Divi Augusti. Bibliotheca Scriptorum Graecorum et Romanorum Teubneriana. Stuttgart: BG Teubner.

Hoffmann R (2010) Latin Word Order Revisited: Information Structure of Topic and Focus. In P Anreiter and M Kienpointer (eds), 267-279. Latin Linguistics Today. Akten 15. Internationalen Kolloquiums zur Lateinischen Linguistik Innsbruck, 4.-9. April 2009. Innsbruck: Beiträge zur Sprachwissenschaft 137. Innsbruck.

de Jong JR (1991) Word order in Cato's De Agricultura. In J. Herman, (ed), 91-101. Linguistic Studies on Latin. Selected Papers from the 6th International Colloquium 
on Latin Linguistics (Budapest, 23-27 March 1991). Studies in Language Companion 28. Amsterdam-Philadelphia: J. Benjamins.

Kirchner R (2001) Sentenzen im Werk des Tacitus. Palingenesia 74. Stuttgart: Franz Steiner.

Koestermann E (1969) P. Cornelii Taciti Libri Qui Supersunt II/2: Historiarum Libri. Bibliotheca Scriptorum Graecorum et Romanorum Teubneriana. Leipzig: BG Teubner.

Koestermann E (1970) P. Cornelii Taciti Libri Qui Supersunt II/2: Germania, Agricola, Dialogus de Oratoribus (3rd edn). Bibliotheca Scriptorum Graecorum et Romanorum Teubneriana. Leipzig: BG Teubner.

Koestermann E (1971) P. Cornelii Taciti Libri Qui Supersunt I: Ab Excessu Divi Augusti (3rd edn). Bibliotheca Scriptorum Graecorum et Romanorum Teubneriana. Leipzig: BG Teubner.

Kühner R, Stegmann C (1962) Ausfürliche Grammatik der Lateinischen Sprache, 2/1, 2/2 (Satzlehre 4th ed). Munich: M. Hueber.

Leumann E, Hofmann JA, Szantyr A $(1963,1964)$ Lateinische Syntax und Stilistik. Handbuch der Altertumswissenschaft, II, 2/2. Munich: CH Beck.

Lewis CT, Short C (1879) A Latin Dictionary. Oxford: Clarendon Press (repr. 1996).

Löfstedt B (1967) Bemerkungen zum Adverb im Lateinischen. Indogermanische Forschungen 72: 79-109.

Lundström S (1961) Abhinc und Ante: Studien zur Geschichte der Lateinischen Zeitdifferenzbestimmungen. Acta Reg. Societatis Humaniorum Litterarum Lundensis 62. Lund: CW K Gleerup.

Marouzeau J (1948) Quelques vues sur l' ordre des mots en latin. Lingua 1: 155-161.

Marouzeau J (1949) L'order des mots dans la phrase Latine. Les Articulations L'Énoncé 3. Collection d'études latines publiée par la Société des Études Latines (Série Scientifique 24). Paris: Les belles lettres.

Mendell CW (1911) Sentence Connection in Tacitus. Doctoral Dissertation, Yale University. New Haven \& London.

Menge H (1961) Repetitorium der Syntax und Stilistik (16th edn). Bearbeit von A. Thierfelder). Münich: M. Hueber.

Menge H (1988) Lateinishe Synonymik ( th $^{\text {th }}$ ed). O. Schonberger (ed). Heidelberg: C Winter.

Miller NP (1994) Tacitus Annals XV. London: Bristol Classical Press (repr. 2001).

Önnerfors A (1983) P. Cornelius Tacitus Libri Qui Supersunt. De Origine et Situ Germannorum Liber II/2. Bibliotheca Scriptorum Graecorum et Romanorum Teubneriana. Stuttgart: BG Teubner.

Pinkster H (1972) On Latin Adverbs. North-Holland Linguistic Series 6. Amsterdam: North Holland Publishing Company.

Pinkster H (1990) Latin Syntax and Semantics. Translated by Holze Multer. London-New York: Routledge.

Risselada R (1996) And Now for something completely different? Temporal discourse marks: Latin nunc and English now. In R Risselada, Jan R De Jong and M Bolkstein (eds). On Latin Linguistic and Literary Studies in Honour of Harm Pinkster. Amsterdam: JC Gleben.

Römer F (1976) P. Corneli Taciti Annalium Libri XV-XVI. Wiener Studien: Zeitschrift für klassische Philologie und Patristik, 6. Wien-Köln-Graz: Böhlau.

Schaffner-Rimann J (1958) Die Lateinischen Adverbien auf -tim. Dissertation Zürich. Winterthur: PG Keller.

Schinzel I (1971) P. Corneli Taciti Historiarum Lib. II. Wiener Studien. Zeitschrift für klassische Philologie und Patristik, 3. Wien-Köln-Graz: Böhlau. 
Solodow JB (1978) The Latin Particle Quidem. American Classical Studies 4. Boulder. Boulder, Colorado: Johnson.

Voss BR (1963) Der pointierte Stil des Tacitus. Orbis Antiquus 19. Münster: Aschendorff. Weiskopf H (1973) P. Corneli Taciti Annalium Libri XI-XII. Wiener Studien. Zeitschrift für klassische Philologie und Patristik, 4. Wien-Köln-Graz: Böhlau.

Winterbottom M, Ogilvie RM (1975) Taciti Opera Minora. Oxford Classical Texts. Oxford: Oxford University Press.

Wolf E (1926) P. Cornelii Taciti Historiarum Libri Qui Supersunt II, Buch III-V. (2nd ed). Berlin: Weidmann.

Woodcock EC (1992) Tacitus. Annals XIV. London: Bristol Classical Press (repr. 2001).

Woodman AJ, Martin RH (1996) The Annals of Tacitus, Book 3 (Cambridge Classical Texts and Commentaries 32). Cambridge: Cambridge University Press (repr. 2004). 